\title{
The role of the state in increasing labor productivity in agricultural enterprises of Ukraine
}

\author{
Sergey Yekimov 1,*, Volidymyr Sarychev ${ }^{2}$, Natalya Malyuga ${ }^{3}$, Liudmyla Shkulipa ${ }^{4}$, and \\ Anastasiia Poltorak ${ }^{5}$ \\ ${ }^{1}$ Publishing House "Education and Science" s.r.o., Praha 8, Olstynska 607/1, Praha, 18100 Czech \\ Republic \\ ${ }^{2}$ University of Customs and Finance, Dnipro, Ukraine \\ ${ }^{3}$ Polissia National University, Zhytomyr, Ukraine \\ ${ }^{4}$ National Academy of Statistics, Accounting and Audit, Kyiv, Ukraine \\ ${ }^{5}$ Mykolayiv National Agrarian University, Mykolayiv, Ukraine
}

\begin{abstract}
In this article examines the economic and management reasons for the low profitability of most Ukrainian agricultural enterprises. Due to the low level of salaries, there is a shortage of qualified service personnel. Approximately $90 \%$ of agricultural machinery in the fields is obsolete or worn out. The younger generation tends to go to work in the city. Increasing labor productivity will reduce the costs of agricultural enterprises and contribute to the successful functioning of the labor market. Professional development, training and retraining of personnel are essential for agricultural enterprises. Enterprises without government support are experiencing difficulties in solving this problem.In our opinion, an active role of the state in training workers in the agricultural sector of the economy will help to reduce the level of migration of labor resources from rural areas to cities.An increase in the level of responsibility of employees, in our opinion, can be achieved through training and subsequent state certification, with the aim of using their professional knowledge and skills in the future.
\end{abstract}

\section{Introduction}

Labor is one of the most important factors of production in an agricultural enterprise. Labor productivity determines the efficiency of the enterprise. Successful development of the enterprise requires constant search for ways to increase labor productivity

The economic essence of increasing the level of labor productivity is to reduce production costs per unit of output.

According to Yavorska, T. (2019) the increase in labor productivity allows you to:

1) Increase production volumes;

2) Reduces labor costs for the production of one unit of production;

\footnotetext{
* Corresponding author: 3701313@mail.ru
} 
3) Increases the profitability of production.

In the opinion of Kostiuk, Victoria \& Usyk, Kateryna. (2019) in improving labor productivity, the qualification of employees, the use of high-performance agricultural technologies and various forms of motivation of employees of the enterprise are of great importance.

Authors Prus, Yurii \& Yavorska, Tetiana \& Voronianska, Olena \& Petryha, Olexiy. (2019) it is noted that labor productivity at an agricultural enterprise depends on material and technical , socio-economic , organizational and economic, and natural and geographical factors.

According to Shevchenko, Alisa \& Petrenko, Olga \& Orlova, Victoria. (2020) the level of labor productivity is influenced by: production, regional, national and human factors.

The staff of agricultural enterprises has a number of specific features and consists of permanent and seasonal employees. Professional requirements for permanent employees are usually higher. They must have certain skills, knowledge and experience of working in an agricultural enterprise. Seasonal workers, as a rule, are used in low-skilled, laborintensive production and for them the main thing is the availability of an appropriate health condition that allows them to perform their work.

According to Khomoviy, S. \& Tomilova, N. \& Khomovju, M. (2018) the level of efficiency of an agricultural enterprise depends on the professional training of employees of the enterprise and their possession of the skills necessary to perform their official duties.

According to Lipych, Lubov \& Bortnik, Svitlana \& Tovsteniuk, Oleksandr \& Khilukha, Oksana \& Kushnir, Myroslava. (2017) it is possible to distinguish a number of specific features that are inherent in agricultural production:

1) The main means of production is land;

2) The productivity of labor is greatly influenced by natural and climatic conditions;

3) The production cycle in an agricultural enterprise takes a long time interval, compared to industrial enterprises.

4) Seasonal nature of production;

5) Low investment attractiveness due to the long payback period.

6) Purchase prices for agricultural products have seasonal fluctuations, and are also highly dependent on the situation of the agricultural market.

7) Part of the production of an agricultural enterprise is directed to its own consumption.

According to Novak, N. \& Ihnatenko, M.. (2020), Vasylchenko, Oleksii. (2018) the level of productivity of agricultural production is significantly influenced by the labor and social activity of the company's personnel. It, in turn, depends on the level of professional training of employees, socio-economic conditions in rural areas and the use of advanced agricultural technologies in an agricultural enterprise.

In the opinion of Kyrylov, Yu \& Hranovska, V.. (2019) improving the productivity of an agricultural enterprise contributes to:

1) Improvement of the enterprise management system.

2) Creation of an enterprise information system for more effective communication between departments, as well as individual employees.

3) Organization and automation of workplaces.

4) Creation of a system of training and retraining of employees.

5) Increase employee motivation.

6) Providing employees with social protection and various guarantees.

At the disposal of the enterprise there are many opportunities to increase labor productivity and each agricultural enterprise can choose its own path, taking into account the peculiarities of its functioning. 
However, at present, most agricultural enterprises in Ukraine have a low level of profitability, in addition, about $90 \%$ of agricultural machinery is worn out or obsolete, wages are low compared to other sectors of the economy, there is a shortage of qualified specialists. The younger generation does not want to work in the countryside and strive to go to the city.

Therefore, in our opinion, the majority of Ukrainian agricultural enterprises cannot independently improve the professional training of their employees. Enterprises do not have the necessary resources for this and, therefore, in our opinion, it is necessary to use other approaches.

When writing this article, we used the analytical method; this made it possible to explore a number of issues studied in this article in their unity and development. Taking into account the objectives and goals of this study, we applied a functional research method, this allowed us to study a number of issues related to the role of the state in increasing labor productivity at agricultural enterprises in Ukraine.

\section{Results}

In our opinion, the increase in labor productivity can be achieved by increasing the labor potential of agricultural production. According to Zakharchuk, Oleksandr. (2019) there is a close correlation between labor resources, labor potential and potential labor opportunities of the population.

According to Kucher, Anatolii. (2018), Popov, Andriy. (2017) labor potential is determined by the availability of labor reserves, which are characterized by educational, professional, and other characteristics, the implementation of which is possible under certain circumstances.

The authors believe Mokrytska, H. \& Muniv, R. \& Batyk, B.. (2018) that the level of labor potential of the agricultural sector of the economy is influenced by the quality of professional training, the number and duration of working hours of personnel working in agricultural enterprises, as well as the level of unemployment in rural areas.

In our opinion, the labor potential of agriculture in Ukraine can be considered the potential ability of the rural population, as well as seasonal workers to realize their labor activity in the agricultural sector of the economy.

According to Sharopatova, Anastasia \& Olentsova, Julia. (2020), Slavkova, Olena \& Novikova, Olha. (2015) the low level of development of agricultural production in Ukraine is associated with insufficient technical equipment of agricultural enterprises, poor condition of rural infrastructure. The agricultural production has a seasonal nature of activity, which leads to fluctuations in the needs of labor resources, and this negatively affects the unemployment rate in the country as a whole. All this, in our opinion, does not contribute to the necessary motivation of employees, and in turn leads to a decrease in the level of training of labor resources. In our opinion, labor potential depends on socioeconomic, natural and climatic conditions.

To attract young specialists to agricultural production, it is necessary to improve the state of social and living conditions in rural areas. An important problem of the agricultural sector of the economy is the insufficient legal regulation of the land market; there are also contradictions between regulatory documents and the real state of affairs in rural areas. There are differences in work between state control bodies and local government bodies.

The effective use of labor potential depends on the level of professional competence and the degree of motivation of employees of an agricultural enterprise.

The catastrophic drop in production in the agricultural sector of the Ukrainian economy led to an increase in unemployment, a decrease in the income of the rural population and the destruction of social infrastructure. Financial resources of local budgets do not allow 
solving all these problems, and serious state financial assistance is required in this sector of the economy.

In our opinion, to increase the labor potential in rural areas, a state program is needed to support the development of social and transport infrastructure in rural areas, the development of medical services for the population and the level of education. We believe that the introduction of special social norms and standards in rural areas is required. These measures will not only contribute to the development of the agricultural sector of the economy, the level of its competitiveness in the external and internal markets, but will also guarantee the food security of the state.

Increasing the level of labor potential can also be achieved through advanced training, training and professional retraining of agricultural workers.

Significant incentives for employees to improve their professional level are the possibility of increasing wages because of acquiring new professional skills.

In our opinion, although agricultural enterprises are interested in qualified employees, many of them prefer to look for ready-made specialists on the side, and not engage in professional training of their own. This is due to the fact that a trained specialist can change his place of work and the funds spent on his training will be a loss for the enterprise.

We believe that the application of tax incentives for agricultural enterprises for vocational training of employees will not have the desired effect, since this will affect the rural budgets that are underfunded.

Advanced training of personnel of agricultural enterprises is beneficial to the state. This is because the competitiveness of labor resources and the efficiency of their use are increasing. At the same time, for the enterprise itself, this factor will increase labor productivity and the quality of products. For workers of agricultural enterprises, raising the level of their qualifications will significantly raise the level of wages and allow them to realize their career growth.

Improving the system of training and retraining of personnel will contribute to labor activity and the demand for workers at agricultural enterprises; however, we believe that the state should play the main role in this process. We adhere to the point of view mandatory state certification of personnel of enterprises in the agricultural sector of the economy is required. This, in our opinion, will increase the responsibility of workers for the level of their professional training, carried out with the participation of the state.

\section{Discussion}

The labor is a product of the interaction of labor resources and means of production. Labor productivity in an agricultural enterprise is influenced by production, socio-economic, as well as natural and climatic factors. The reserves for increasing the level of labor productivity are in close correlation with these factors. The reserves for the growth of labor productivity arise with the improvement of the applied technologies, the improvement of the organization of the production process, as well as the influence of scientific and technological progress.

The search for possible reserves for the growth of labor productivity can be carried out by comparing the existing level of labor productivity, as well as the possibility of increasing it, because of making changes in the production process. An increase in labor productivity, in most cases, is associated with the use of new agro-technical technologies, and, as a rule, will require additional training of employees of an agricultural enterprise.

Since productivity increases are based on the principle of maximizing impact while minimizing costs, it may be more beneficial for farm managers to hire another employee with more and better skills. This will facilitate the functioning of the labor market. However, this will also require the creation of conditions for the training and retraining of 
specialists of higher qualifications. To solve this problem without the help of the state, in our opinion, is difficult.

Agricultural workers have alternative employment opportunities associated with moving to the city. On the one hand, this will allow solving the problem of unemployment in rural areas, but at the same time, it will not contribute to attracting highly qualified labor force to agriculture, which means it will restrain the growth of labor productivity at enterprises in the agricultural sector.

\section{Conclusions}

The main reasons that hinder the realization of labor potential in Ukraine, in our opinion, are the low level of qualifications of the personnel of agricultural enterprises, as well as the lack of necessary motivating incentives for highly productive labor activity.

We believe that the main condition for enhancing economic activity in the agricultural sector of the economy is the creation of favorable conditions for the realization of labor potential. This requires not only certain actions on the part of employers, but also effective actions on the part of the state aimed at creating the necessary conditions under which the implementation of labor potential will be most effective.

Increasing labor motivation, full-fledged functioning of the labor market and lowering the unemployment rate require solving a set of problems associated with the social and economic development of the village. In our opinion, an important factor in solving this problem is professional development, training and retraining of workers of agricultural enterprises. Enterprises themselves, without state support, will not be able to solve this problem on their own due to lower wages compared to the industrial sector of the economy, which in turn contributes to the migration of labor resources from rural areas to cities.

In our opinion, the active role of the state in training agricultural workers will help to reduce the intensity of this migration. Strengthening the level of responsibility of workers themselves for their participation in vocational training, as well as providing agricultural enterprises with a state program for certification of workers, their professional knowledge and skills.

\section{References}

1. S. Khomoviy, N. Tomilova, M. Khomovju, Ekonomika ta upravlìnnâ APK, 115 (2018)

2. Yu. Kyrylov, V. Hranovska, Investytsiyi: praktyka ta dosvid, 5 (2019)

3. Victoria Kostiuk, Kateryna Usyk, Market Infrastructure (2019)

4. Anatolii Kucher, Land concentration and competitiveness of agricultural enterprises in Ukraine (2018)

5. Lubov Lipych, Svitlana Bortnik, Oleksandr Tovsteniuk, Oksana Khilukha, Myroslava Kushnir, Problems and Perspectives in Management, 15, 53 (2017)

6. H. Mokrytska, R. Muniv, B. Batyk, Scientific Messenger of LNU of Veterinary Medicine and Biotechnologies, 20, 119 (2018)

7. N. Novak, M. Ihnatenko, Agrosvit, 18 (2020)

8. Andriy Popov, Economic Annals-XXI, 164, 56 (2017)

9. Yurii Prus, Tetiana Yavorska, Olena Voronianska, Olexiy Petryha, Analyses of Personnel Usage at Agricultural Enterprises (2019)

10. Anastasia Sharopatova, Julia Olentsova, Tools of Labor Productivity Management at Agricultural Enterprises (2020) 
11. Alisa Shevchenko, Olga Petrenko, Victoria Orlova, Scientific Horizons, 23, 68 (2020)

12. Olena Slavkova, Olha Novikova, International Journal of New Economics and Social Sciences, 1, 103 (2015)

13. Oleksii Vasylchenko, Economic Analysis, 110 (2018)

14. T. Yavorska, Scientific papers of tavria state agrotechnological university (economic sciences), 39, 286 (2019)

15. Oleksandr Zakharchuk, Ekonomika APK, 48 (2019) 